Polasik M., Piotrowski D., Payment innovations in Poland: the role of payment services in the strategies of commercial banks, „Ekonomia i Prawo. Economics and Law”, Polszakiewicz B., Boehlke J. (ed.), Vol. 15, No. 1/2016, pp. 73-101. DOI: http://dx.doi.org/10.12775/EiP.2016.006.

\title{
PAYMENT INNOVATIONS IN POLAND: THE ROLE OF PAYMENT SERVICES IN THE STRATEGIES OF COMMERCIAL BANKS
}

\author{
SUMMARY
}

This paper examines the significance of innovations in the area of payment services for strategies implemented by commercial banks in Poland. We propose a definition of payment innovations and present the evolution of their introduction in the Polish market, indicating the impact of legal regulations and the critical character of the new FinTech phenomenon. The analysis that we conducted was based on the results of a survey which obtained responses from 24 commercial banks representing almost the entire Polish retail banking sector based on the number of personal accounts maintained. The study helped to determine the main elements of the strategies implemented by banks in Poland. It also revealed the methods for competing in the area of payment services utilized by the banks, with innovative services as one

"Michał Polasik, Nicolaus Copernicus University, Faculty of Economic Sciences and Management, Departament of Finance, ul. Gagarina 13A, 87-100 Toruń, Poland, phone: +48 5661146 34, e-mail: michal.polasik@umk.pl (corresponding author).

** Dariusz Piotrowski, Nicolaus Copernicus University, Faculty of Economic Sciences and Management, Departament of Finance, ul. Gagarina 13A, 87-100 Toruń, Poland, phone: +48 5661146 34, e-mail: darius@econ.umk.pl.

- The article was funded by The Warsaw Institute of Banking and ALTERUM Grant No. WIB/2014/01. We would like to thank Anna Iwona Piotrowska and Natalia Kumkowska, who served as investigators. Moreover, we would like to thank Lech Kukliński, Ph.D. the director of ALTERUM and director Paweł Widawski Ph.D. and Radosław Kotkowski from the Polish Bank Association for their support in carrying out this research project. 
of the leading elements. The results of the study indicated that there was a significant differentiation of applied strategies depending on a bank's size. In the case of larger banks, the main motivation for introducing payment innovations was characteristic of an offensive strategy, and for smaller banks - more often a defensive one. We also proposed a theoretical model for using the specific nature of payment innovations to build customer relationships and to apply cross-selling.

Keywords: payment innovation; bank strategy; payment services; FinTech; payment card

JEL Classification: E42; G21; L21; O31

\section{INTRODUCTION}

Until recently, banks were perceived as conservative institutions which were not prone to taking risks related to introducing new, unverified solutions. This was also true in the area of payment services. As a result, in the beginning of the 1990s, banks offered a limited range of payment products to consumers. In addition to cheques and cash services, including money orders, there was the widespread use of bank transfers ordered in the branch and payment cards, and in certain countries also the use of direct debit. However, the services that were offered were not diversified and not well-developed ${ }^{1}$. The extremely slow process of technological changes in the field of payment cards is a good example. In the first period of their use, i.e. starting in 1950, companies applied the technology of embossing cards on paper with the use of an imprinter ${ }^{2}$. The solution based on the magnetic stripe which allowed electronic reading of the data saved in the card was first introduced in 1971. It took another 20 years until the next technological innovation, which was when the first cards with microprocessors were introduced in 1992. Their common standard EMV was established in $1999^{3}$. Although microprocessor cards had numerous advantages, in particular a high security level and multiapplicability, their introduction was a very slow process. In most EU countries, cards were not fully migrated to that standard until the second decade of the $21^{\text {st }}$ century. This is in spite of the fact that banks were obliged to do

${ }^{1}$ M. Polasik, T.P. Wisniewski, G. Lightfoot, Modelling customers' intentions to use contactless cards, "International Journal of Banking, Accounting and Finance", Vol. 4, No. 3/2012, pp. 203-231; M. Polasik, K. Maciejewski, Innowacyjne ustugi ptatnicze w Polsce i na śrwiecie, "Materiały i Studia NBP", No. 241/2009.

${ }_{2}$ P. Frazer, Plastic and Electronic Money, Woodhead-Faulkner, Cambridge 1985, p. 266.

3 M. Ward, EMV card payments - An update, "Information Security Technical Report", Vol. 11, No. 2/2006, pp. 89-92. 
so through the SEPA self-regulatory programme until $2010^{4}$. In the meantime, the first bank contactless cards were introduced in $2002^{5}$. Although they are characterised by their speed of operation and convenience for consumers ${ }^{6}$, they have gained popularity only in only a few countries, such as the United Kingdom, Poland, Canada and Turkey.

However, it appears that despite this slow process of payment card evolution, technological advancements created new development opportunities for different areas of payment services. It was encouraged by the character of banking services which are most often of an immaterial nature and consist in exchanging information. Moreover, the high level of product standardisation favoured the automation of service. The implementation of innovations in the field of customer communication also gave rise to significant benefits for banks in the form of cost reductions and an increase in the geographical range of the banks' impact ${ }^{7}$. A surge of communication effectiveness allowed banks to implement additional innovations for individual financial services. As a result, a large number of innovative products have emerged in recent years and the banking sector shows great interest in new technologies $^{8}$. The importance of this phenomenon is indicated by the appearance of the term "FinTech" distinguishing technological innovations in the financial sector'. This process is also very noticeable in Poland, in particular in the payment services segment ${ }^{10}$. The widespread introduction of payment innovations

${ }^{4}$ European Payments Council, Making SEPA a Reality - The definitive Guide to the Single Euro Payments Area, EPC066-06, Brussels 2009; European Payments Council, Recommendation on an End Date for Migration to SEPA Schemes, EPC362-08, Brussels 2009; M. Polasik, K. Przenajkowska, Integracja europejska i innowacje na rynku ustug ptatniczych na rynku ustug ptatniczych, Fundacja Warszawski Instytut Bankowości, Warszawa 2013.

${ }^{5}$ M. Polasik, T.P. Wisniewski, G. Lightfoot, op. cit., pp. 203-231.

${ }^{6}$ M. Polasik et al., Time efficiency of Point-of-Sale payment methods: Empirical results for cash, cards and mobile payments, "Lecture Notes in Business Information Processing", Springer, Heidelberg, Vol. 141/2013, pp. 306-320.

7 M. Polasik, K. Maciejewski, op. cit.; M. Polasik, Bankowośc elektroniczna: istota, stan, perspektywy, CeDeWu, Warszawa 2007, pp. 41-42.

${ }^{8}$ D. Spath et al., European Trend Survey "BANKS \& FUTURE 2012". Trends and Developments in the European Payments Market, Stuttgart 2012; Committee on Payment and Settlement Systems, Innovations in retail payments, Basel 2012; S. Chakravorti, E. Kobor, Why invest in payment innovations?, "Federal Reserve Bank of Chicago Emerging Payments Occasional Paper”, No. 2003-1B/2003.

9 T. Dapp, Fintech - The digital (r)evolution in the financial sector, "Deutsche Bank Research", Frankfurt am Main 2014.

${ }^{10} \mathrm{~J}$. Harasim, M. Klimontowicz, Payment habits as a determinant of retail payment innovations diffusion: the case of Poland, "Journal of Innovation Management", Vol. 1, No. 2/2013, 
gives rise to a question regarding their impact on strategies implemented by banks, which is a new and very interesting field for scientific studies.

The paper aims to determine the significance of payment innovations for strategies implemented by commercial banks in Poland. Its specific objectives are: (1) to study the impact of the scale of the bank's operations on competitive strategies in the area of payment services and (2) to determine banks' expectations regarding the results of implementing payment innovations. As mentioned above, Poland has recently seen a dynamic development of the payment services market and the banks' introduction of many new solutions. This led the authors to present the following research hypothesis: The innovativeness of payment services is an important tool for competing in the retail banking market in Poland.

\section{DEFINITION OF PAYMENT INNOVATION}

As a starting point, we adopted the definitions of these terms used by OECD" 11 "A product innovation is the introduction of a good or service that is new or significantly improved with respect to its characteristics or intended uses. This includes significant improvements in technical specifications, components and materials, incorporated software, user friendliness or other functional characteristics". Whereas "a process innovation is the implementation of a new or significantly improved production or delivery method. This includes significant changes in techniques, equipment and/or software". In the case of payment innovations, the element of novelty or an improvement are introduced in the service, in the process of its provision, or both at the same time ${ }^{12}$. The most frequent novelties or improvements are related to technological advancements, expanding functionalities or increasing convenience. It should be emphasized that innovation is considered from the viewpoint of its perception by the consumer or organization ${ }^{13}$.

The use of the term payment innovations in this paper refers primarily to product and/or process innovations which are financial innova-

pp. 86-102; P. Wannemacher, A. L'Hostis, 2015 Global Mobile Banking Functionality Benchmark, Cambridge 2015; M. Polasik, K. Maciejewski, op. cit.

${ }^{11}$ OECD, Eurostat, Oslo Manual: Guidelines for Collecting and Interpreting Innovation Data, $3^{\text {rd }}$ Edition, Paris 2005.

${ }^{12}$ J. Harasim, M. Klimontowicz, op. cit., pp. 86-102; A. Iwańczuk-Kaliska, Innowacje w ptatnościach detalicznych jako wyzwanie dla banków centralnych, "Problemy Zarządzania", Vol. 13, No. 3/2015, pp. 41-53.

${ }^{13}$ E.M. Rogers, Diffusion of Innovations, Free Press, New York 1983, p. 11. 
tions in the narrow sense. However, in accordance with the classification by M. Marcinkowska ${ }^{14}$, the work uses to a certain limited extent the broad approach to financial innovations because we also take into consideration new infrastructural solutions which are the necessary environment for providing certain new payment services. In this paper, innovations in the field of infrastructure may also include certain marketing and organisational innovations. Two examples of infrastructure innovations included in our studies are: newly created clearing systems which allow for offering instant payments, and platforms supporting a common standard for mobile payments.

Taking into consideration all the above fields of innovation, the authors proposed their own definition according to which: A payment innovation is the introduction of a payment service that is new or significantly improved with respect to its characteristics or intended uses, as well as the implementation of method of delivery of payment services or a solution in the field of technical and business infrastructure which is employed to provide payment services.

\section{BANK STRATEGIES IN THE MODERN ECONOMY}

Since the 1990s, the formation of the banking system in Poland was under the strong influence of processes observed around the world, such as deregulation, internationalisation and globalisation of operations ${ }^{15}$. We also observed the intensification of competition from non-bank entities, increased significance of new technologies, including the Internet, the decrease of margins obtained in traditional business, and demographic and cultural chang$\mathrm{es}^{16}$. The study conducted by Delis indicated that in the years 1999-2006 it was the Polish banking market that boasted the highest competition lev-

${ }^{14}$ M. Marcinkowska, Innowacje finansowe w bankach, "Acta Universitatis Lodziensis. Folia Oeconomica”, No.266/2012, pp. 71-96.

15 S. Kasiewicz, L. Kukliński, M. Marcinkowska, Sektor bankowy - motor czy bamulec wzrostu gospodarczego, ALTERUM Ośrodek Badań i Analiz Systemu Finansowego, Zakład Warszawskiego Instytutu Bankowości, Warszawa 2013, pp. 17-18, 93; W. Piotrowicz, Information Technology and Systems in the Visegrád Group of Countries (Czech Republic, Hungary, Poland, and Slovakia): A Literature Review, "Journal of Global Information Technology Management”, Vol. 18, No.2/2015, pp. 77-93.

${ }^{16}$ E. Gostomski, Kierunki rozwoju bankowości detalicznej na świecie, [in:] A. Szelągowska (ed.), Wspótczesna bankowośc detaliczna, CeDeWu, Warszawa 2010, pp. 15-30; M. Kisiel, Internet a konkurencyjnośc banków w Polsce, CeDeWu, Warszawa 2005, p. 31. 
el in Central and Eastern Europe ${ }^{17}$. The rising level of competition made bank managers aware of the need to constantly update and implement operating strategies ${ }^{18}$. In the beginning, a strategy was understood as a long-term plan or decision-making process in which emphasis was placed on resources at the bank's disposal which allowed, after identifying the strengths and weaknesses of the organisation, to act adequately to the arising challenges ${ }^{19}$. The gradual saturation of the market with banking services, increasing customer awareness, and as a result - customer requirements, heralded the transition from a seller's market to a customer's market. Under new conditions, customers and their needs became the most important element of the bank's environment considered in the process of strategic management. Modern market strategies, although they take into account the significance of resources, place special emphasis on specific skills and competences which allow banks to react quickly and benefit from emerging opportunities or reduce threats ${ }^{20}$. Moreover, strategies are characterised by certain dynamics of changes in time, directed to achieving the assumed objective ${ }^{21}$.

Modern banks apply operating strategies which commonly constitute a combination of several methods of achieving the assumed objectives, distinguished by theorists ${ }^{22}$. If we use a division of strategies taking into account the scope of the bank's operations, we can distinguish ${ }^{23}$ :

- universalisation of operations - the bank's offer is diversified and apart from classic products it also includes insurance and investment products,

- specialisation of operations - the bank focuses on satisfying specified, narrowly defined financial needs of its customers through providing relatively uniform, specialised products.

17 M.D. Delis, Competitive conditions in the Central and Eastern European banking systems, “Omega”, Vol. 38, No. 5/2010, pp. 268-274.

${ }_{18}$ D. Korenik, Konkurencyjnośc $i$ konkurencja banków polskich od lat dzierwięćdziesiątych XX wieku (rynek klientów indywidualnych i gospodarczych), Wydawnictwo Akademii Ekonomicznej we Wrocławiu, Wrocław 2002, p. 40.

${ }^{19}$ R. Krupski, J. Niemczyk, E. Stańczyk-Hugiet, Koncepcje strategii organizacji, PWE, Warszawa 2009, p. 13.

${ }^{20} \mathrm{~J}$. Rokita, Zarzqdzanie strategiczne. Tworzenie i utrzymywanie przewagi konkurencyjnej, PWE, Warszawa 2005, pp. 20-21.

${ }^{21}$ T. Doligalski, Model biznesu z perspektywy ogólnej teorii systemów, [in:] T. Doligalski (ed.), Modele biznesu w Internecie. Teoria i studia przypadków polskich firm, PWN, Warszawa 2014.

${ }^{22}$ W. Wrzosek, Strategie marketingowe, PWE, Warszawa 2012.

${ }^{23}$ J. Canals, Scale versus specialization: banking strategies after the euro, "European Management Journal", Vol. 17, No. 6/1999, pp. 567-575. 
With respect to the actions regarding the share of a given bank in the market, we can propose the following division of strategies ${ }^{24}$ :

- offensive strategy which aims to increase market share,

- defensive strategy focused on maintaining the existing market position.

From among the strategies aimed at growth, J. Grzywacz distinguishes ${ }^{25}$ :

- market penetration, where through innovative activities or differentiation of the product the bank strives to acquire new customers in the existing market;

- territorial expansion which is characterised by geographically broader bank's impact range while it maintains the existing product offer;

- exploring new markets through expanding the service offer.

As regards the method of achieving competitive advantage, we have ${ }^{26}$ :

- strategy based on low operating costs - the bank applies service standardisation and offers basic services to the customers. This strategy may lead to an outbreak of a price war $^{27}$;

- differentiation strategy - the bank tries to stand out from the competition by creating an innovative and unique product offer. The application of this strategy is associated with large financial outlays on research and marketing and the need to have a creative team of employees;

- concentration strategy - in which the bank applies one of the abovementioned strategies to a limited range of services or in a limited geographic area.

In turn, with respect to the type of product offered by the bank we can distinguish the following marketing strategies ${ }^{28}$ :

- aggregation strategy - the bank offers barely diversified products on a mass scale;

- market segmentation — the bank provides a group of customers having homogeneous features with products adjusted to their specific needs;

${ }^{24}$ J. Liebena, T. Khiaonarong, Banking on Innovation. Modernisation of Payment Systems, Physica-Verlag, Heidelberg 2009.

25 J. Grzywacz, Marketing w dziatalności banku, Difin, Warszawa 2006, p. 35.

${ }^{26}$ R. Shaw, The Bank is Dead, Long Live the Bank, [in:] E.P.M. Gardener, P.C. Versluijs (eds.), Bank Strategies and Challenges in the New Europe, Palgrave Macmillan UK, Basingstoke 2001, pp. 1-18; M. Kisiel, op. cit.

${ }_{27}$ M. Matłoka, Banki mogq zarabiaí więcej. Potrzeba jednak zmian w procesach wyceny innowacji i podwyżek cen, http://prnews.pl/analizy/banki-moga-zarabiac-wiecej-potrzeba-jednakzmian-w-procesach-wyceny-innowacji-i-podwyzek-cen-3342363.html (17.04.2016).

28 T. Grzegorczyk, Strategie marketingowe banków, PWN, Warszawa 1997; M. IwaniczDrozdowska, W.L. Jaworski, Z. Zawadzka, Bankowość. Zagadnienia podstawowe, Poltex, Warszawa 2010. 
- product differentiation - the bank tries to acquire and maintain customers by introducing product improvements and modifications;

- innovative strategy - the factor differentiating the bank from the competition is the constant introduction of innovations which respond to current and future customer needs.

In general, strategies implemented by banks today fulfil, to a large extent, the demands of the concept of the so-called effective competition ${ }^{29}$. It combines the bank's benefits with customer satisfaction, it leads to progress through the implementation of technological and organisational innovations, and its final effect is the possibility to choose from among products attractive with respect to price and quality ${ }^{30}$. In turn, competing takes the form of rivalry, it is associated with creativity and not elimination. This promotes building a positive image of the stability of the sector as a whole ${ }^{31}$. The abovementioned individual theoretical views on market strategies applied in the banking sector served us to conduct an in-depth analysis of the issue of introducing an offering modern payment services in the Polish market.

\section{APPLICATIONS OF INFORMATION TECHNOLOGIES IN PAYMENT SERVICES IN THE CONTEXT OF THE DEVELOPMENT OF THE POLISH BANKING SECTOR}

The first years of transformation of the Polish economy after 1989 were a period of substantial changes in the banking sector. There was a departure from the monopolistic position of the central bank, firstly for the benefit of state banks, and later also private banks ${ }^{32}$. Another change was expressed in moving away from restrictions in the functioning of banks regarding the type of entities serviced, the scope of services provided and geographical location of businesses. Changes in quality were accompanied by a dynamic growth of the number of banks. In 1989, the market comprised 18 commer-

${ }^{29}$ J.A. Bikker, K. Haaf, Measures of competition and concentration in the banking industry: A review of the literature, "Economic \& Financial Modelling", No. Summer/2002; C.M. Bender, G. Götz, B. Pakula, Effective competition: its importance and relevance for network industries, "Intereconomics: review of European economic policy", Vol. 46/2011, pp. 4-10.

${ }^{30}$ D. Korenik, Konkurencyjność..., op. cit., p. 12.

${ }^{31}$ D. Korenik, Bank i jego ustugi w dobie „rewolucji finansowej”, [in:] D. Korenik (ed.), Innowacyjne ustugi banku, PWN, Warszawa 2006, pp. 15-43; L. Pawłowicz, Reflections about too big to fail banks and moral hazard, "Bezpieczny Bank", No. 60/2015, pp. 78-88.

32 J. Węcławski, Przeksztatcenia polskiego systemu bankowego w latach 1989-2014, "Annales UMCS — Sectio H Oeconomia”, Vol. XLIX, No. 1/2015, pp. 189-199. 
cial banks, and in 1993 there were already 87 of them ${ }^{33}$. The next two decades were marked by consolidation processes resulting in a reduction of the number of banks. Numerous studies around the world have proven that sector consolidation gives rise to a positive impact of the economies of scale ${ }^{34}$, although not in all cases banks benefited from combining different scopes of operations $^{35}$. In the case of the Polish market, however, it was proven that thanks to consolidation banks achieved a growth of effectiveness ${ }^{36}$ and benefited from the advantages of economies of scale ${ }^{37}$. It can be assumed that in general this process allowed banks to increase investment outlays, including outlays related to the implementation of payment innovations.

An important stage in the development of the banking sector was the implementation of innovative IT solutions based on the Internet network, which gave rise to a change in the methods of customer service, including in the scope of banks' clearing services ${ }^{38}$. Since its introduction in Poland in $1998^{39}$, Internet banking perfectly fulfilled its role as a channel taking over the provision of standard banking services, such as obtaining information about the account balance, and primarily — ordering a bank transfer. The Internet channel allowed banks to reduce fixed costs as a result of reducing costs of employment and branch maintenance. Some banks tried to benefit from the reduction of costs by applying the so-called virtual banking strategy, in which they resigned from using a network of branches to service the customer, and relied only on electronic channels ${ }^{40}$. This strategy led to a radical reduction of costs of servicing retail customers. It was then typically used to apply intense price competition in order to acquire a large number of new customers ${ }^{41}$. In the first development stage virtual banking may be considered an almost model example of using the low operating costs strat-

33 S. Kasiewicz, Zarys przysztego modelu bankowości komercyjnej, [in:] J. Szambelańczyk (ed.), Polski sektor bankowy w perspektywie roku 2030, Oficyna Wydawnicza SGH, Warszawa 2010.

${ }_{34}$ W. Bolt, D.B. Humphrey, Payment network scale economies, SEPA, and cash replacement, "Review of Network Economics", Vol. 6, No. 4/2007, pp. 453-473.

35 J.A. Clark, Economies of scale and scope at depository financial intuitions: A review of the literature, "Federal Reserve Bank of Kansas City Economic Review", No. Q3/1988, pp. 16-33.

${ }^{36}$ M. Pawłowska, T. Słaby, Analiza efektów skali w sektorze banków z zastosowaniem metod statystycznych, "Bank i Kredyt”, Vol. 35, No. 11-12/2004, pp. 74-81.

37 G. Gikas, Korzyści skali w sektorze bankowym, "Bank i Kredyt", Vol. 31, No. 11/1999, pp. 70-73.

${ }^{38}$ J. Harasim et al., Europejski rynek ptatności detalicznych, CeDeWu, Warszawa 2011.

${ }_{39}$ M. Polasik, T.P. Wisniewski, Empirical analysis of internet banking adoption in Poland, "International Journal of Bank Marketing", Vol. 27, No. 1/2009, pp. 32-52.

${ }^{40}$ M. Polasik, op. cit.

${ }^{41}$ M. Polasik, T.P. Wisniewski, op. cit., pp. 32-52. 
egy combined with market penetration and territorial expansion strategies. On the other hand, a large part of multichannel banks (offering a branch network) used the Internet in the applied defensive strategy connected with product differentiation. Studies performed in the United States have indicated that in general the virtual banking strategy was characterised by lower profitability than the multichannel strategy ${ }^{42}$. However, it was successfully applied in the Polish market by mBank which achieved a positive financial result after more than four years of activity in the virtual banking model. Generally, studies covering the Eurozone countries have confirmed that the introduction of Internet banking had a positive impact on banks' performance but it resulted from the reduction of banks' fixed costs and not from an increase in revenue $^{43}$. Another important example of the application of innovations to reduce costs is the introduction of debit cards which since late 1990s have been issued in Poland to practically all current accounts. In the first period, their main function was to allow customers to withdraw cash in ATMs, and thus to unburden cashier's desks in bank branches. The strategy of low costs was applied also in this case. However, it was combined with the aggregate approach focused on providing a mass and barely diversified product. New empirical studies were necessary to verify whether the pursuit of cost reduction is still an important motivation for introducing payment innovations.

It should be noted that in comparison to payment services offered within Internet banking, payment cards have become an attractive source of revenue for banks operating in Poland. 99\% of payment cards issued to customers functioned within the four-party card schemes of Visa and MasterCard ${ }^{44}$. The promotion of their use to make payments and not only to withdraw cash from ATMs led to development of cashless transactions in Poland ${ }^{45}$. Owing

${ }^{42}$ R. DeYoung, Learning-by-doing, scale efficiencies, and financial performance at Internetonly banks, "Federal Reserve Bank of Chicago Working Paper Series", No. WP-01-06/2001; R. DeYoung, T. Rice, How do banks make money? A variety of business strategies, "Economic Perspectives", Vol. 28, No. 4/2004, pp. 52-67.

${ }^{43}$ K.B. Tunay, N. Tunay, İ. Akhisar, Interaction between Internet banking and bank performance: The case of Europe, "Procedia - Social and Behavioral Sciences", Vol. 195/2015, pp. 363-368; I. Hernando, M.J. Nieto, Is the Internet delivery channel changing banks' performance? The case of Spanish banks, "Journal of Banking and Finance", Vol. 31, No. 4/2007, pp. 1083-1099.

${ }^{44}$ For more details on the functioning of the four-party card schemes, see: J.C. Rochet, J. Tirole, Must-take cards: Merchant discounts and avoided costs, "Journal of the European Economic Association”, Vol. 9, No. 3/2011, pp. 462-495; J.C. Rochet, J. Tirole, Externalities and regulation in card payment systems, "Review of Network Economics", Vol. 5, No. 1/2006, pp. 1-14.

${ }^{45}$ E. Sokolowska, Innovations in the payment card market: The case of Poland, "Electronic Commerce Research and Applications”, Vol. 14/2015, pp. 292-304. 
to the high level of the Interchange Fee (IF) ${ }^{46}$, charged by banks from trading and service companies which accepted cards, banks achieved a hefty income calculated on the value of payment transactions with the use of debit and credit cards ${ }^{47}$. At the same time, this mechanism provided funds for ambitious implementations of innovations such as the migration of practically the whole Polish market to the contactless cards standard ${ }^{48}$. However, the high interchange fee prompted the Polish regulator to statutorily reduce it ${ }^{49}$. As a result, there was a series of two IF reductions in mid-2014 and in early 2015. The cumulative reduction of the fee was extremely high and amounted to as much as 4.3 times for credit cards and 6.5 times for debit cards. Abrupt decrease of banks' revenue achieved thanks to payment cards was undoubtedly a regulatory shock. Concerns were voiced in relation to these changes in the banking environment which were unfavourable for banks. There were fears that the processes of introducing FinTech innovations in the Polish market may be curbed. Verification of whether the threat of fulfilment of this negative scenario is probable required an examination of the banks' plans regarding the involvement in implementing payment innovations in the coming years, which was one of the aims of the second article in the series ${ }^{50}$.

\section{METHOD OF EMPIRICAL RESEARCH}

Empirical studies applied in the paper were conducted as part of a research project of the Warsaw Institute of Banking Rozwój przez innowacje czy efekt skali? Badanie uczestników polskiego systemu ptatniczego [Development through innovations or economies of scale? Study of the participants of the Polish payment system] (No. WIB/2014/01). The project was implemented in the years 2014-2015 by a team under the direction of Michal Polasik, within ALTERUM Centre for Research and Analysis of Financial System. It aimed

46 In 2012, average interchange fee rates were highest among all countries in the European Union (Narodowy Bank Polski, Program redukcji optat kartowych w Polsce, Warszawa 2012).

${ }^{47}$ A. Börestam, H. Schmiedel, Interchange fees in card payments, "ECB Occasional Paper Series", No. 131/2011.

${ }_{48}$ M. Polasik, T.P. Wisniewski, G. Lightfoot, op. cit., pp. 203-231.

${ }^{49} \mathrm{~J}$. Górka, Merchant indifference test application - A case for revising interchange fee level in Poland, "The usage, costs and benefits of cash - revisited. Proceedings of the 2014 International Cash Conference", Deutsche Bundesbank, Frankfurt am Main 2014, pp. 75-151.

${ }_{50}$ M. Polasik, D. Piotrowski, Payment innovations in Poland: A new approach of the banking sector to introducing payment solutions, "Ekonomia i Prawo. Economics and Law", Vol. 15, No. $1 / 2016$. 
to study the strategic approach of banks to the implementation of payment innovations, the role the innovations play in their offers, and the forecasts regarding market changes until 2020.

The main survey study of the project was addressed to institutions involved in the functioning of the payment services market. Questions were asked of the executives (CEOs) of banks and other institutions, and the responses obtained were their official positions regarding the studied issues. The questionnaire was distributed via bodies operating at the Polish Bank Association, i.e.: the Banking Cards Issuers Council, the Electronic Banking Council, the Acquirers Committee and SEPA Poland. The survey was conducted in the period from June until December 2014. The obtained research sample of institutions included: 24 commercial banks, 11 cooperative banks and associations and 10 acquirers and payment processors. Commercial banks which participated in the survey had a ca. $94 \%$ share in the total number of current accounts, and the participating paying agents held $81 \%$ of EFTPOS and covered $88 \%$ of card transactions in Poland. Therefore, the results of the study are representative with respect to the issuance and acceptance network for retail payment instruments in Poland.

For the purposes of the analysis conducted in this paper we use the results of survey in the scope of answers given by commercial banks ${ }^{51}$. The sample of $n=24$ commercial banks was arranged according to the number of current accounts maintained and divided according to the median. It allowed us to use additional categories in detailed analyses: "Larger banks" for the group of 12 commercial banks with the largest number of current accounts and "Smaller banks" for the group of the other 12 banks. Such division enabled us to study the relation of the scale of a bank's operations to the strategy it implements and involvement in the implementation of innovative payment services.

\section{PRIMARY ELEMENTS OF COMPETITION STRATEGIES OF RETAIL BANKS IN THE POLISH MARKET}

Institutions participating in the survey were asked to indicate the most important elements in the retail banking strategies they apply (figure 1). The vast

${ }^{51}$ The summary of remaining results of the study is available on the website of the ALTERUM: M. Polasik, A. Piotrowska, N. Kumkowska, Rozwój przez innowacje czy efekt sali? Badanie uczestników polskiego systemu ptatniczego. Streszczenie kierownicze, http://alterum.pl/ uploaded/Raport_Rozwoj_przez_innowacje_czy_efekt_skali_-_polski_s.pdf (17.04.2016). 
majority of banks agreed that the most important element of the strategy was high quality of services offered. The next two places were taken by strengthening the relationship with existing customers and acquiring new customers. For larger commercial banks, the strengthening of customer relations was even equally important as the high quality of services.

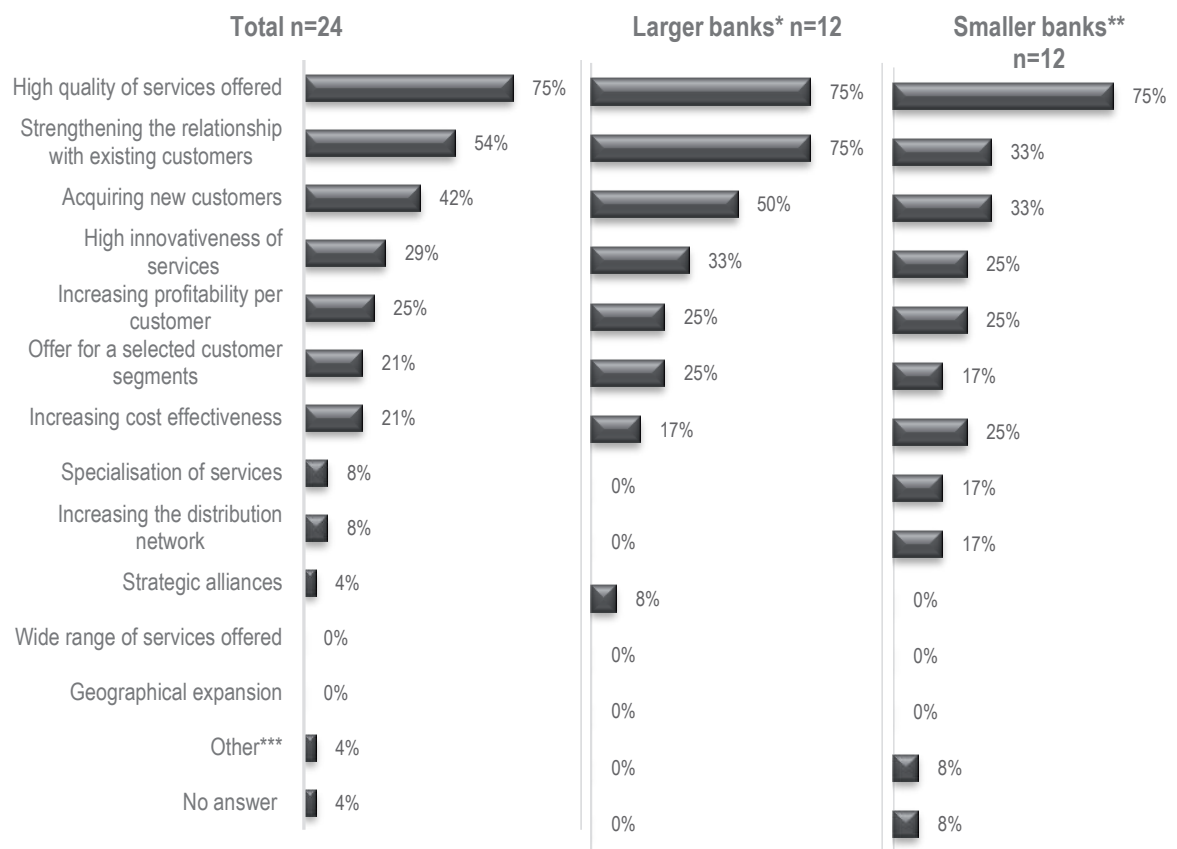

Figure 1. Most important elements of strategies (by size of bank)

* "Larger banks" - means the 12 commercial banks with the largest number of current accounts maintained; ** "Smaller banks" - means the group of the remaining 12 commercial banks with a smaller number of current accounts maintained; ${ }^{\star \star \star ~ ' F i n a n c i a l ~ d i s c o u n t ' ~ s t r a t e g y ~ w a s ~ d e c l a r e d . ~}$

Source: Survey among commercial banks; a maximum of three answers; Q1. Which elements are the most important in the retail banking strategy of your Bank?

High innovativeness of services was in fourth position within strategies of commercial banks; it was selected fewer times by smaller institutions than by larger banks ${ }^{52}$. Therefore, it can be assumed that for institutions in the payment services market innovation is not an aim in itself, but it should be used to offer high quality services, expand customer relations and acquire new customers.

${ }^{52}$ J. Harasim, Strategie marketingowe w osiaganiu przewagi konkurencyjnej w bankowości detalicznej, Wydawnictwo Akademii Ekonomicznej we Wrocławiu, Wrocław 2004, p. 75. 
Only around a quarter of commercial banks indicated the significance of financial aspects, such as increasing profitability per customer and cost effectiveness, with the last element relatively more important for smaller commercial banks. Some of the banks also indicated a strategy consisting in offering services to selected segments. Other elements of strategies were indicated only in single cases.

Interesting conclusions may be drawn from the analysis of the results of the survey taking into account the division of banks with regard to their size. Smaller banks use more diverse development strategies than larger institutions. This diversification is better visible when we exclude from the analysis the most important element of strategies for all banks, i.e. high quality of services offered. Some of the smaller banks still see an opportunity to apply the strategy of expansion through development of the distribution network, and to a limited extent, the specialisation strategy which allows the bank and its offer to stand out from among universal credit institutions operating in the country.

The fact that a bank emphasises high quality of services provided does not determine the type of strategy used by the bank. This is because high quality may be observed both in offensive and defensive strategies, in strategies assuming both universalisation and specialisation of operations. The combination of high quality of services offered with the intension to strengthen relationships with existing customers may indicate a defensive strategy intended to maintain the market share with the use of the differentiation strategy. However, rather numerous indications for factors such as: acquiring new customers, high innovativeness of services and increasing profitability per customer may indicate an offensive character of the strategy used, in which market penetration is applied with the use of the differentiation strategy. Especially that the diversification of products, primarily through the introduction of innovations, combined with the extension of the scale of operations, helps increase profitability. Another method of increasing profitability may be the segmentation of customers indicated by the respondents.

The relatively high position of increasing cost effectiveness could suggest that some banks were applying the aggregation strategy. However, we have to take into account all abovementioned elements of declared strategies, in particular innovativeness which is the opposite of simplicity and standardisation of services. Therefore the indications of increasing cost effectiveness should be rather read as a general cost rationalization, not the implementation of the aggregation strategy. In one case, a bank's strategy was based on lower operating costs and price competition because the respondent characterised its operations as those of a financial discount. 


\section{INNOVATIVENESS OF PAYMENT SERVICES AS AN ELEMENT OF BANKS' STRATEGIES}

In this part of the paper we focus on learning the role of payment innovations in the general strategy and their significance for methods of competing in the field of payment services. The analysis of responses obtained indicates that most commercial banks (figure 2) want to compete in the field of payment services by providing four key features to the customers: (a) innovativeness of services, (b) convenience of use, (c) multiple channels and (d) security of services. With reference to the above, we can assume that the most important common element of strategies of most banks is the provision of innovativeness of payment services. These results disclose much bigger significance of innovativeness in the payment services segment in comparison to the general strategy of banks (figure 1).
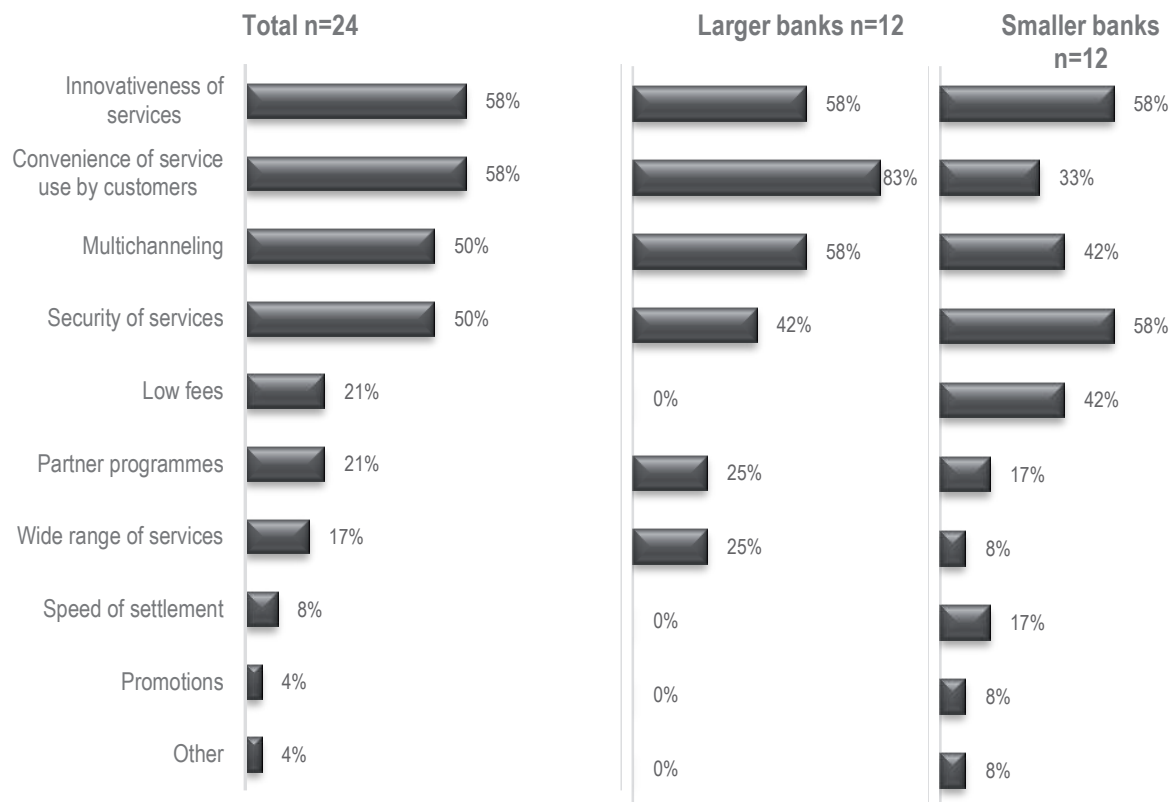

Figure 2. Methods of competing in the field of payment services (by size of bank)

Source: Survey among commercial banks; a maximum of three answers; Q2. How does your Bank want to compete with other banks in the field of payment services?

The analysis of data divided into larger and smaller banks helps observe significant differences in the methods of competing in the field of payment services (figure 2). In the case of larger banks the predominant manner of achieving competitive advantage is to provide convenience to the cus- 
tomer. Larger banks focus on that aspect and it helps them effectively provide high quality and strengthen relationships with customers (figure 1). The increase of customer convenience is supported by a wide range of service offered supplemented with partner programs which help build longterm relationships with customers. However, these two last elements do not constitute the main methods of competing in the payment services market. It is extremely important that no one larger bank declared competing in fees. It is one of the most visible differences between larger and smaller banks because almost half of the smaller banks consider price competition in their strategies, and in many cases they are willing to apply it even at the cost of lower customer convenience. Smaller banks also put a slightly lower emphasis on multichannelling and extending the scope of services. These banks, in possession of limited resources for investments in innovative solutions, focus on a narrow group of products which makes it harder for them to strengthen relationships with the customer. Therefore, they see their chance in the reduction of fees.

In the case of smaller banks, indications regarding competing by striving to improve customer convenience of the use of payment services (figure 2) should be treated as rather declarative. They pay slightly more attention to the role of security, and only they indicated taking actions to improve the speed of settlement. This may result from a need to introduce more advanced IT solutions in the fields which in large banks have already been improved.

The conducted analysis of methods of competing in the field of payment services allows us to formulate certain conclusions regarding strategies implemented by commercial banks. In the case of large banks the implementation of the indicated solutions gives rise to a need to incur significant investment outlays. Higher functioning costs of banks will be partly transferred to the customers because price competition is not assumed. These characteristics indicate the domination of the strategy of universalisation of operations in which the differentiation strategy is the source of competitive advantage. When analysing the indications of small banks we can assume that price competition will remain a permanent element of the Polish payment services market. To a large extent, the introduction of innovations is to contribute to the improvement of technological and cost effectiveness of the services which are already offered. As a result, banks will be able to offer lower fees for these services to the customers. Although in the case of smaller banks we have an element of cost reduction, the declared methods of competing indicate the use of the differentiation strategy based on the product innovation strategy, as well as integration with an innovative payment infra- 
structure. On the other hand, the conscious reduction of the scope of services points to elements of the concentration strategy.

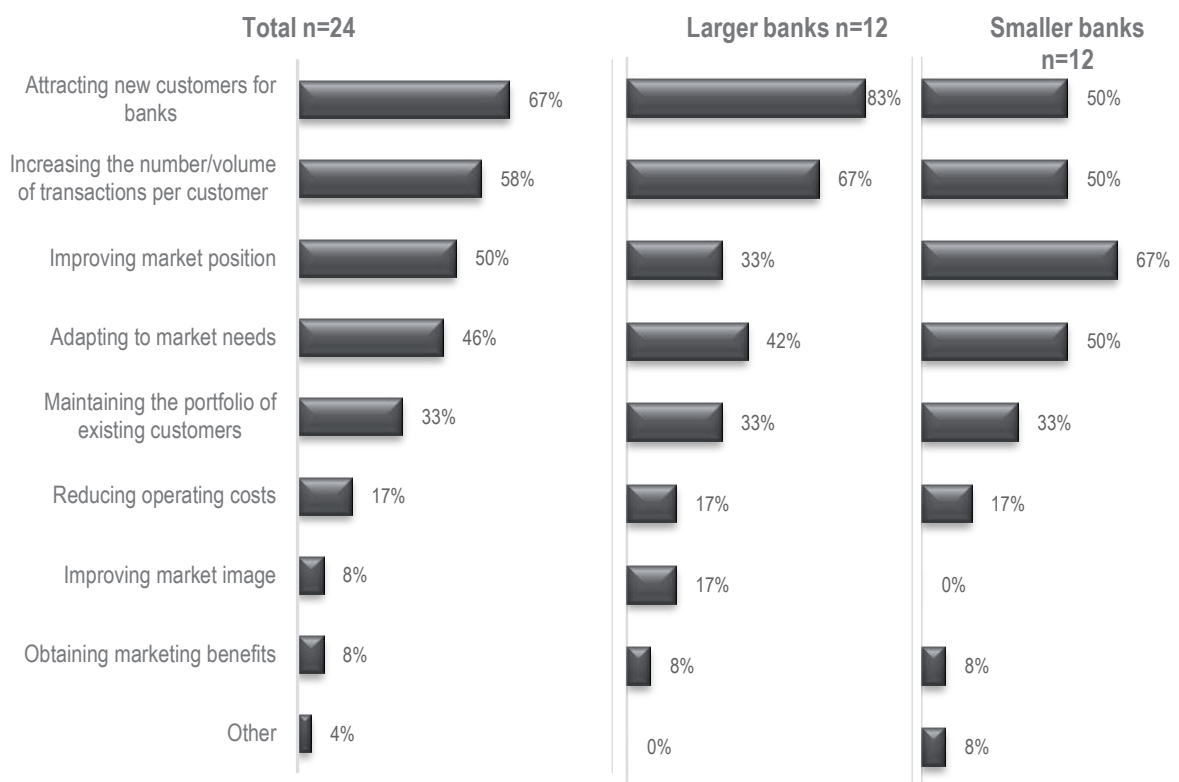

Figure 3. Main reasons for introducing payment innovations (by size of bank)

Source: Survey among commercial banks; a maximum of three answers; Q3. What are the main reasons for introducing payment innovations by your Bank?

The main motivation of the banks for becoming involved in the implementation of payment innovations is the willingness to attract new customers (figure 3). In particular, this regards larger commercial banks, with more than $80 \%$ of these institutions declaring that objective. Improving market position and increasing the number/volume of transactions per customer are two further reasons. In this case, larger commercial banks place bigger importance on the increase in the number/volume of transactions, while for smaller commercial banks the most important objective for introducing innovations is the improvement of market position. For them, the attraction of new customers, increase in the number/volume of transactions per customer and adjustment to market needs are equally in second place.

The results we obtained confirmed ${ }^{53}$ that payment innovations are no longer perceived primarily in the context of marketing benefits or image improvement (only several indications of the respondents). Payment innovations

${ }_{53}$ M. Polasik, K. Przenajkowska, op. cit., p. 45. 
have become a core element of banks' market strategies, and the indicated reasons show that large banks use these innovations to implement offensive strategies. They strive to attract new customers and increase the number/volume of transactions, what in turn may result both in improved profitability achieved on a given customer and in the increase of the bank's share in the financial activities of the customer (in the case the customer uses the services of many banks). In the case of smaller banks (figure 3), it is harder to definitely indicate whether using payment innovations is an element of offensive or defensive strategies. However, it seems that there is a slight advantage of defensive elements such as: improving market position, adjusting to market needs (including to trends set by innovation leaders), and maintaining the portfolio of existing customers. To sum up, the presented empirical results suggest the confirmation of research hypothesis, according to which the innovativeness of payment services is an important tool for competing in the retail banking market in Poland. The studies conducted indicate that innovativeness is an important element of the general strategy of banks, and in the field of payment services it is actually the key factor of competitive advantage.

\section{A MODEL FOR USING THE TRANSACTIONAL NATURE OF PAYMENT SERVICES FOR THE IMPLEMENTATION OF STRATEGIC OBJECTIVES OF A BANK}

Moreover, identified reasons for introducing payment innovations lead us to consider the development of payment services as an activity aimed at achieving objectives formulated in bank strategies. The specific nature of payment services make them a particularly convenient tool for the implementation of the general strategy of banks in the scope of strengthening relationships with the customer ${ }^{54}$. Payment innovations, mostly through the increase of convenience ${ }^{55}$, contribute to increasing the number and volume of transactions per customer and maintaining the portfolio of exist-

${ }^{54}$ Deloitte, Payments disrupted. The emerging challenge for European retail banks, London 2015, https://www2.deloitte.com/content/dam/Deloitte/uk/Documents/financial-services/deloitte-ukpayments-disrupted-2015.pdf (17.04.2016).

55 The significantly positive impact of the convenience of use of contactless cards and mobile payments on their perceived utility, and the resulting consumer interest in these innovations were indicated in the previous studies, see: M. Polasik, N. Kumkowska, Determinanty zainteresowania ptatnościami mobilnymi ze strony polskich konsumentów, "Problemy Zarządzania", Vol. 13, No. 3/2015, pp. 102-117; M. Polasik, T.P. Wisniewski, G. Lightfoot, op. cit., pp. 203-231. 
ing customers. This is caused by the fact that frequent payment transactions force the customer to provide adequate funds to carry them out, usually by providing regular inflows to the bank account from the source of income, and to monitor them on a regular basis ${ }^{56}$. Therefore, an efficient method for strengthening relationships with the customers and for maintaining existing customers or acquiring new ones is to encourage consumers to frequently carry out payment transactions. Thanks to such specifics, payment services may play an extremely important role both in an offensive and a defensive bank strategy. In particular, they have a big potential to allow the bank to apply cross-selling ${ }^{57}$.

We proposed a model for using the transactional nature of payment services to implement the strategic objectives of a bank, presented in graph 1 . Its key element is the activation of customers to carry out transactions more frequently. Method A consists in introducing innovations which provide consumers with high convenience and is a method of competing commonly applied in the Polish market, especially by large banks (figure 2). On the other hand, method B includes motivating consumers to carry out transactions more frequently through the fee structure and financial incentives, and its effectiveness was empirically proven ${ }^{58}$. Smaller banks may also apply it as an element of price competition. The presented typical methods of using the specific features of payment services allow the bank to implement both an offensive and a defensive strategy. The ultimate objective of these actions is to increase or maintain the current level of sales and profitability, also through applying cross-selling.

${ }^{56}$ Deloitte, op. cit.

${ }^{57}$ Ibidem; M. Panowicz, M. Seralis, B. Witorzeńć, Marketing transakcyjny, czyli jak efektywnie wykorzystać możliwości analityczne oraz wiedze o kliencie do zwiększenia sprzedaży. mOkazje - case study, [in:] Z. Jagiełło (ed.), Wyzwania bankowości detalicznej, Instytut Badań nad Gospodarką Rynkową, Gdańsk 2015, pp. 22-39.

${ }^{58}$ J. Marzec, M. Polasik, P. Fiszeder, Wykorzystanie gotówki i karty ptatniczej w punktach handlowo-ustugowych w Polsce: zastosowanie dwuwymiarowego modelu Poissona, "Bank i Kredyt", Vol. 44, No. 4/2013, pp. 375-402; M. Polasik et al., Modelowanie wykorzystania metod ptatności detalicznych na rynku polskim, "Materiały i Studia NBP”, No. 265/2012. 


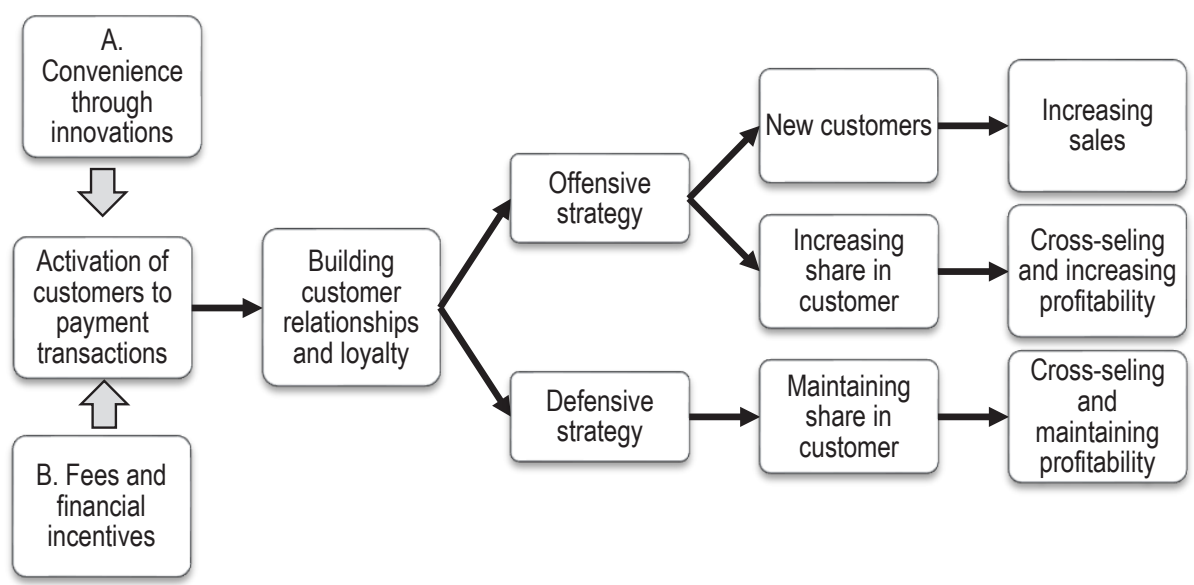

Graph 1. A model for using the transactional nature of payment services to implement the strategic objectives of a bank

It is worth noting that in comparison to other bank services, such as deposits, loans or investment products, in the case of payment services it is harder for the customer to cherry-pick ${ }^{59}$, i.e. use only the most attractive offers simultaneously in several banks because it would necessitate current management of the cash balance and an effort to register numerous services. With reference to the foregoing, we can assume that payment services are generally characterised by high customer loyalty. On the other hand, basic payment services are of a very standard character, and price competition in the provision thereof is very intensified ${ }^{60}$. Therefore, in order to stand out in the market banks need to introduce innovations in that field.

\section{STRATEGIC APPROACH OF BANKS TO PAYMENT INNOVATIONS}

The results of the conducted studies indicate that both the payment services provided and the innovations implemented within those services have become a very important element of market strategies of commercial banks in Poland. However, this situation should be analysed in the broader context of the development of European banking, where low rates and decreasing credit margins, increasingly restrictive regulations and high level of com-

59 D. Rambure, A. Nacamuli, Payment systems. From the Salt Mines to the Board Room, Palgrave Macmillan, Basingstoke 2008, p. 206.

${ }^{60}$ S. Chakravorti, E. Kobor, op. cit. 
petition in the sector contribute to a drop in profitability in traditional areas of banking activity ${ }^{61}$. Therefore, payment services supported by the FinTech industry appear as a prospective development area, especially in the situation of promoting cashless society ${ }^{62}$, that should lead to significant growth of the transaction volume ${ }^{63}$.

In this context, it is important to consider the question of whether banks are actually capable of achieving financial benefits thanks to introducing innovations. Research conducted by the company Simon-Kucher \& Partners in more than 40 countries around the world ${ }^{64}$ pointed to a general problem with achieving profitability for the introduced banking innovations. It appears that only $23 \%$ of newly-introduced banking products achieve the assumed profitability level, and the performance of the banking sector in that field is worse than in most industries. The main reason is that as many as $59 \%$ of banks covered by the Global Pricing Study 2014 were engaged in a price war $^{65}$. In this context, it seems particularly beneficial that only $21 \%$ of Polish commercial banks participating in our survey (figure 2) declared competing in the field of payment services on the basis of low fees. Notably, none of the larger banks was interested in a price war. However, it is worth mentioning that in the case of payment innovations it is particularly hard to achieve a higher profit margin as a premium for being an innovation lead$\mathrm{er}^{66}$. This results from the impact of network externalities ${ }^{67}$. They are respon-

${ }^{61}$ Speech by Yves Mersch, Member of the Executive Board of the ECB, at the European Financial Forum dinner, 2015 Cumberland Lodge Financial Services Summit, Cumberland Lodge, 12 November 2015, https:/www.ecb.europa.eu/press/key/date/2015/html/sp151112_1.en.html (17.04.2014).

${ }^{62}$ Koalicja na Rzecz Obrotu Bezgotówkowego i Mikropłatności, Program Rozwoju Obrotu Bezgotówkowego w Polsce na lata 2014-2020, Warszawa 2013, http://zbp.pl/dla-bankow/zespoly-rady-i-komitety/podaj-nazwe/obrot-bezgotowkowy/koalicja (17.04.2016).

${ }^{63}$ C. van der Cruijsen, M. Plooij, Changing payment patterns at point-of-sale: their drivers, "DNB Working Paper", No. 471/2015.

${ }^{64}$ The Global Pricing Study 2014 conducted in cooperation with an independent association - Professional Pricing Society, covered around 1.600 managers, including over $600 \mathrm{mem}$ bers of management boards, from over 40 countries; (Simon-Kucher \& Partners, Global Pricing Study 2014. Kryzys w innowacyjności? 72\% nowych produktów wprowadzanych na rynek to porażki, Warszawa 2014, http://www.simon-kucher.com/sites/default/files/global_pricing_study_2014_ podsumowanie.pdf (17.04.2016).

${ }^{65}$ M. Matłoka, op. cit.

${ }^{66}$ S. Chakravorti, E. Kobor, op. cit.

${ }^{67} \mathrm{~J}$. Church, N. Gandal, D. Krause, Indirect network effects and adoption externalities, "Review of Network Economics", Vol. 7, No. 3/2008, pp. 337-358; V. Stango, The economics of standards wars, "Review of Network Economics", Vol. 3, No. 1/2004, pp. 1-19; G. Gowrisankaran, J. Stavins, Network externalities and technology adoption: Lessons from electronic payments, "RAND 
sible for the fact that when the initial number of users is small, the value of the newly-introduced payment service for consumers is significantly limited. Therefore, banks are forced to initiate diverse promotional programmes in order to acquire a large number of customers for the new service so that the number of users reaches critical mass ${ }^{68}$. As a result, in the period of early adoption of an innovation banks incur additional outlays to promote it and usually refrain from charging customers with fees, contrary to other industries where, such as in the computer industry, the highest margin is obtained from selling novelties ${ }^{69}$. Accordingly, it seems unlikely that the main driving force for the implementation of innovations is the achievement of profitability on these products in a short-term perspective ${ }^{70}$.

One important factor which is conducive to the implementation of payment innovations by banks is surely the possibility to use the specific features of payment services to achieve additional objectives. As we have discussed in chapter 7, by inducing customers to carry out a sufficiently large number of payment transactions, banks can increase their loyalty, which is an excellent basis for cross-selling and combining products in packages ${ }^{71}$. Moreover, while only a small group of banks declares improving market image or obtaining marketing benefits as the main reason for introducing a payment innovation (figure 3), apparently innovations are after all used as a tool supporting the achievement of these objectives. This is indicated by the intense competition between banks in the field of media coverage aiming to reach the position of innovation leader ${ }^{72}$. The introduction of a novel product really gives the bank a chance to appear in the media and obtain favourable positioning of the bank's brand.

Journal of Economics", Vol. 35, No. 2/2004, pp. 260-276; S. Chakravorti, Externalities in payment card networks: Theory and evidence, "Review of Network Economics", Vol. 9, No. 2/2010.

${ }^{68}$ C. Arango, K.P. Huynh, L. Sabetti, Consumer payment choice: Merchant card acceptance versus pricing incentives, "Journal of Banking \& Finance", Vol. 55/2015, pp. 130-141; J. Górka, Efektywnośc instrumentów ptatniczych w Polsce, Wydawnictwo Naukowe Wydziału Zarządzania Uniwersytetu Warszawskiego, Warszawa 2013.

${ }^{69}$ E.M. Rogers, op. cit.

${ }^{70} \mathrm{G}$. Hansen, Innowacje w bankach sq mato zyskowne, ale daja inny efekt, http://www.obserwatorfinansowy.pl/tematyka/bankowosc/innowacje-w-bankach-sa-malo-zyskowne-ale-daja-inny-efekt/?skad=newsletter20160225 (17.04.2016).

71 Deloitte, op. cit.

72 G. Hansen, op. cit. 


\section{CONCLUSIONS}

The paper examines the significance of innovations in the area of payment services for strategies implemented by commercial banks in Poland. We started by explaining the general factors influencing the use of modern IT technology in the banking services sector. We subsequently proposed our own definition of payment innovations, including elements of product and process innovation, as well as new infrastructural solutions. The characteristics of the main types of bank strategies that were presented, helped us to create a theoretical framework for a discussion based on the empirical results. The paper also presents the most important examples of the implementation of IT for the provision of payment services which have had an impact on the development of the Polish banking sector. This analysis resulted in an important conclusion pointing to solutions which aim to reduce costs, i.e. payments based on Internet banking and the use of ATMs, as well as innovations generating revenue for banks, such as debit and credit cards used for cashless transactions.

The analysis was based on the results of a survey of commercial banks which represent almost the entire market share of the Polish retail banking sector. It helped to determine the general strategies implemented by banks in Poland. Empirical results indicate that in the current market situation, the high quality of the services provided may be seen as one of the main sources of its competitive advantages. At the same time, it helps implement the strategy of strengthening long-term relationships with customers which is key for large banks. Increasing cost effectiveness is less important and is primarily of interest for smaller banks. On the other hand, innovativeness is not an aim in itself for institutions in the financial services market. However, it should serve to offer high quality services, expand customer relations and to acquire new customers.

The work also analyses the methods in which banks compete in the area of payment services, with high innovativeness of such services as the leading element. It is an important hallmark of payment services against a background of the general strategy of commercial banks. These results also indicate that there is a material differentiation of applied strategies depending on the bank size. In the case of larger banks, the predominant manner of achieving competitive advantage is to provide convenience to the customer, which allows banks to provide high quality and strengthen relationships with its customers. On the other hand, almost half of smaller banks assume the possibility to compete with low fees. As a result, price competition will remain a perma- 
nent element of the Polish payment services market. The analysis of the main reasons why banks become involved in implementing payment innovations has indicated that larger banks use these innovations to implement offensive strategies. They strive to attract new customers and increase the number and volume of transactions. This, in turn, may result in both improved profitability achieved on a given customer and in the increase of the bank's share in the financial activities of the customer. In the case of smaller banks, there is an advantage of defensive elements such as: improving market position, adjusting to market needs and trends, and maintaining the portfolio of existing customers. Employing the analysis of the survey study and the results of other studies, we proposed a theoretical model for the use of the transactional nature of payment services to implement the strategic objectives of a bank. The empirical evidence and theoretical considerations presented in the paper clearly indicate that current payment services already perform a very important role in the strategies of commercial banks, which proves the research hypothesis proposed in the paper.

In the second article in the series, entitled Payment innovations in Poland: A new approach of the banking sector to introducing payment solutions ${ }^{73}$, we present the results of the banks' execution of the abovementioned strategies in the form of the scope of implementations of payment innovations and the declared plans for the coming years. We also tackle the issue of the significance of economies of scale and network externalities, technological advances in the FinTech industry and the results of regulatory reduction of the interchange fee on the development of payment innovations in Poland.

\section{BIBLIOGRAPHY}

Arango C., Huynh K.P., Sabetti L., Consumer payment choice: Merchant card acceptance versus pricing incentives, "Journal of Banking \& Finance", Vol. 55/2015, http:// doi.org/10.1016/j.jbankfin.2015.02.005.

Bender C.M., Götz G., Pakula B., Effective competition: its importance and relevance for network industries, "Intereconomics: review of European economic policy", Vol. 46/2011.

Bikker J.A., Haaf K., Measures of competition and concentration in the banking industry: A review of the literature, "Economic \& Financial Modelling", No. Summer/2002.

Bolt W., Humphrey D.B., Payment network scale economies, SEPA, and cash replacement, "Review of Network Economics", Vol. 6, No. 4/2007, http://doi. org/10.2202/1446-9022.1129.

${ }^{73}$ M. Polasik, D. Piotrowski, op. cit. 
Börestam A., Schmiedel H., Interchange fees in card payments, "ECB Occasional Paper Series", No. 131/2011.

Canals J., Scale versus specialization: banking strategies after the euro, "European Management Journal”, Vol. 17, No. 6/1999, http://dx.doi.org/10.1016/s0263-2373(99)00047-x.

Chakravorti S., Externalities in payment card networks: Theory and evidence, "Review of Network Economics", Vol. 9, No. 2/2010. http://doi.org/10.2202/14469022.1199.

Chakravorti S., Kobor E., Why invest in payment innovations?, "Federal Reserve Bank of Chicago Emerging Payments Occasional Paper", No. 2003-1B/2003.

Church J., Gandal N., Krause D., Indirect network effects and adoption externalities, "Review of Network Economics", Vol. 7, No. 3/2008, pp. 337-358. http://doi. org/10.2202/1446-9022.1153.

Clark J.A., Economies of scale and scope at depository financial intuitions: $A$ review of the literature, "Federal Reserve Bank of Kansas City Economic Review", No. Q3/1988.

Committee on Payment and Settlement Systems, Innovations in retail payments, Basel 2012.

Dapp T., Fintech - The digital (r)erolution in the financial sector, "Deutsche Bank Research", Frankfurt am Main 2014.

Delis M.D., Competitive conditions in the Central and Eastern European banking systems, "Omega", Vol. 38, No. 5/2010, http://doi.org/10.1016/j.omega.2008.09.002.

Deloitte, Payments disrupted. The emerging challenge for European retail banks, London 2015, https://www2.deloitte.com/content/dam/Deloitte/uk/Documents/financial-services/deloitte-uk-payments-disrupted-2015.pdf (17.04.2016).

DeYoung R., Learning-by-doing, scale efficiencies, and financial performance at Internet-only banks, "Federal Reserve Bank of Chicago Working Paper Series", No. WP01-06/2001, http://dx.doi.org/10.2139/ssrn.282721.

DeYoung R., Rice T., How do banks make money? A variety of business strategies, "Economic Perspectives", Vol. 28, No. 4/2004.

Doligalski T., Model biznesu z perspektywy ogólnej teorii systemów, [in:] T. Doligalski (ed.), Modele biznesu w Internecie. Teoria i studia przypadków polskich firm, PWN, Warszawa 2014.

European Payments Council, Making SEPA a Reality - The definitive Guide to the Single Euro Payments Area, EPC066-06, Brussels 2009.

European Payments Council, Recommendation on an End Date for Migration to SEPA Schemes, EPC362-08, Brussels 2009.

Frazer P., Plastic and Electronic Money, Woodhead-Faulkner, Cambridge 1985.

Gikas G., Korzyści skali w sektorze bankowym, "Bank i Kredyt", Vol. 31, No. 11/1999.

Górka J., Efektywność instrumentów ptatniczych w Polsce, Wydawnictwo Naukowe Wydziału Zarządzania Uniwersytetu Warszawskiego, Warszawa 2013, http://doi. org/10.7172/978-83-63962-30-2. 
Górka J., Merchant indifference test application - A case for revising interchange fee level in Poland, "The usage, costs and benefits of cash - revisited. Proceedings of the 2014 International Cash Conference", Deutsche Bundesbank, Frankfurt am Main 2014.

Gostomski E., Kierunki rozwoju bankowości detalicznej na świecie, [in:] A. Szelągowska (ed.), Wspótczesna bankowośś detaliczna, CeDeWu, Warszawa 2010.

Gowrisankaran G., Stavins J., Network externalities and technology adoption: Lessons from electronic payments, "RAND Journal of Economics", Vol. 35, No. 2/2004, http://doi.org/10.2307/1593691.

Grzegorczyk T., Strategie marketingowe banków, PWN, Warszawa 1997.

Grzywacz J., Marketing w dziatalności banku, Difin, Warszawa 2006.

Hansen G., Innowacje w bankach sq mato zyskowne, ale daja inny efekt, http://www. obserwatorfinansowy.p1/tematyka/bankowosc/innowacje-w-bankach-sa-malo-zyskowne-ale-daja-inny-efekt/?skad=newsletter20160225 (17.04.2016).

Harasim J., Frączek B., Szustak G., Klimontowicz M., Europejski rynek ptatności detalicznych, CeDeWu, Warszawa 2011.

Harasim J., Klimontowicz M., Payment habits as a determinant of retail payment innovations diffusion: the case of Poland, "Journal of Innovation Management", Vol. 1, No. 2/2013.

Harasim J., Strategie marketingowe w osiaganiu przewagi konkurencyjnej w bankowosci detalicznej, Wydawnictwo Akademii Ekonomicznej we Wrocławiu, Wrocław 2004.

Hernando I., Nieto M.J., Is the Internet delivery channel changing banks' performance? The case of Spanish banks, "Journal of Banking and Finance", Vol. 31, No. 4/2007, pp. 1083-1099. http://doi.org/10.1016/j.jbankfin.2006.10.011.

Iwańczuk-Kaliska A., Innowacje w ptatnościach detalicznych jako wyzwanie dla banków centralnych, "Problemy Zarządzania", Vol. 13, No. 3/2015, http://doi. org/10.7172/1644-9584.54.3.

Iwanicz-Drozdowska M., Jaworski W.L., Zawadzka Z., Bankowość. Zagadnienia podstawowe, Poltex, Warszawa 2010.

Kasiewicz S., Kukliński L., Marcinkowska M., Sektor bankowy - motor czy bamulec wzrostu gospodarczego, ALTERUM Ośrodek Badań i Analiz Systemu Finansowego, Zakład Warszawskiego Instytutu Bankowości, Warszawa 2013.

Kasiewicz S., Zarys przysztego modelu bankowości komercyjnej, [in:] J. Szambelańczyk (ed.), Polski sektor bankowy w perspektywie roku 2030, Oficyna Wydawnicza SGH, Warszawa 2010.

Kisiel M., Internet a konkurencyjność banków w Polsce, CeDeWu, Warszawa 2005.

Koalicja na Rzecz Obrotu Bezgotówkowego i Mikropłatności, Program Rozwoju Obrotu Bezgotówwowego w Polsce na lata 2014-2020, Warszawa 2013, http://zbp.pl/ dla-bankow/zespoly-rady-i-komitety/podaj-nazwe/obrot-bezgotowkowy/koalicja (17.04.2016).

Korenik D., Bank i jego ustugi w dobie „rewolucji finansowej”, [in:] D. Korenik (ed.), Innowacyjne ustugi banku, PWN, Warszawa 2006. 
Korenik D., Konkurencyjnośc i konkurencja banków polskich od lat dziewię́cdziesiatych XX wieku (rynek klientów indywidualnych i gospodarczych), Wydawnictwo Akademii Ekonomicznej we Wrocławiu, Wrocław 2002.

Krupski R., Niemczyk J., Stańczyk-Hugiet E., Koncepcje strategii organizacji, PWE, Warszawa 2009.

Liebena J., Khiaonarong T., Banking on Innovation. Modernisation of Payment Systems, Physica-Verlag, Heidelberg 2009, http://doi.org/10.1007/978-3-7908-2333-2.

Marcinkowska M., Innowacje finansowe w bankach, "Acta Universitatis Lodziensis. Folia Oeconomica", No. 266/2012.

Marzec J., Polasik M., Fiszeder P., Wykorzystanie gotórwki i karty ptatniczej w punktach handlowo-ustugowych w Polsce: zastosowanie dwuwymiarowego modelu Poissona, "Bank i Kredyt", Vol. 44, No. 4/2013.

Matłoka M., Banki mogq zarabiać więcej. Potrzeba jednak zmian w procesach wyceny innowacji i podwyżek cen, http://prnews.pl/analizy/banki-moga-zarabiac-wiecej-potrzeba-jednak-zmian-w-procesach-wyceny-innowacji-i-podwyzek-cen-3342363. html (17.04.2016).

Narodowy Bank Polski, Program redukcji optat kartowych w Polsce, Warszawa 2012.

OECD, Eurostat, Oslo Manual: Guidelines for Collecting and Interpreting Innovation Data, $3^{\text {rd }}$ Edition, Paris 2005.

Panowicz M., Seralis M., Witorzeńć B., Marketing transakcyjny, czyli jak efektywnie wykorzystać możliwości analityczne oraz wiedze o kliencie do zwięszenia sprzedazy. mOkazje — case study, [in:] Z. Jagiełło (ed.), Wyzwania bankowości detalicznej, Instytut Badań nad Gospodarką Rynkową, Gdańsk 2015.

Pawłowicz L., Reflections about too big to fail banks and moral hazard, "Bezpieczny Bank", No. 60/2015.

Pawłowska M., Słaby T., Analiza efektów skali w sektorze banków z zastosowaniem metod statystycznych, "Bank i Kredyt", Vol. 35, No. 11-12/2004.

Piotrowicz W., Information Technology and Systems in the Visegrad Group of Countries (Czech Republic, Hungary, Poland, and Slovakia): A Literature Review, "Journal of Global Information Technology Management", Vol. 18, No. 2/2015, http:// doi.org/10.1080/1097198X.2015.1052684.

Polasik M., Bankowośc elektroniczna: istota, stan, perspektywy, CeDeWu, Warszawa 2007.

Polasik M., Górka J., Wilczewski G., Kunkowski J., Przenajkowska K., Tetkowska N., Time efficiency of Point-of-Sale payment methods: Empirical results for cash, cards and mobile payments, "Lecture Notes in Business Information Processing", Springer, Heidelberg, Vol. 141/2013, http://doi.org/10.1007/978-3-642-40654-6_19.

Polasik M., Kumkowska N., Determinanty zainteresowania ptatnościami mobilnymi ze strony polskich konsumentów, "Problemy Zarządzania", Vol. 13, No. 3/2015, http:// doi.org/10.7172/1644-9584.54.7.

Polasik M., Maciejewski K., Innowacyjne ustugi ptatnicze w Polsce i na świecie, "Materiały i Studia NBP”, No. 241/2009. 
Polasik M., Marzec J., Fiszeder P., Górka J., Modelowanie wykorzystania metod ptatnosci detalicznych na rynku polskim, "Materiały i Studia NBP", No. 265/2012.

Polasik M., Piotrowska A., Kumkowska N., Rozwój przez innowacje czy efekt sali? Badanie uczestników polskiego systemu ptatniczego. Streszczenie kierownicze, http://alterum.pl/uploaded/Raport_Rozwoj_przez_innowacje_czy_efekt_skali_-_polski_s. pdf (17.04.2016).

Polasik M., Piotrowski D., Payment innovations in Poland: A new approach of the banking sector to introducing payment solutions, "Ekonomia i Prawo. Economics and Law”, Vol. 15, No. 1/2016, http://dx.doi.org/10.12775/EiP.2016.007.

Polasik M., Przenajkowska K., Integracja europejska $i$ innowacje na rynku ustug ptatniczych na rynku ustug ptatniczych, Fundacja Warszawski Instytut Bankowości, Warszawa 2013.

Polasik M., Wisniewski T.P., Empirical analysis of internet banking adoption in Poland, "International Journal of Bank Marketing”, Vol. 27, No. 1/2009, http://doi. org/10.1108/02652320910928227.

Polasik M., Wisniewski T.P., Lightfoot G., Modelling customers' intentions to use contactless cards, "International Journal of Banking, Accounting and Finance", Vol. 4, No. 3/2012, http://doi.org/10.1504/IJBAAF.2012.051590.

Rambure D., Nacamuli A., Payment systems. From the Salt Mines to the Board Room, Palgrave Macmillan, Basingstoke 2008.

Rochet J.C., Tirole J., Externalities and regulation in card payment systems, "Review of Network Economics”, Vol. 5, No. 1/2006, http://doi.org/10.2202/14469022.1085.

Rochet J.C., Tirole J., Must-take cards: Merchant discounts and avoided costs, "Journal of the European Economic Association”, Vol. 9, No. 3/2011, http://doi. org/10.1111/j.1542-4774.2011.01020.x.

Rogers E.M., Diffusion of Innovations, Free Press, New York 1983.

Rokita J., Zarzadzanie strategiczne. Tworzenie i utrzymywanie przewagi konkurencyjnej, PWE, Warszawa 2005.

Shaw R., The Bank is Dead, Long Live the Bank, [in:] E.P.M. Gardener, P.C. Versluijs (eds.), Bank Strategies and Challenges in the Nerw Europe, Palgrave Macmillan UK, Basingstoke 2001.

Simon-Kucher \& Partners, Global Pricing Study 2014. Kryzys w innowacyjnośi? 72\% nowych produktów wprowadzanych na rynek to porażki, Warszawa 2014, http:// www.simon-kucher.com/sites/default/files/global_pricing_study_2014_podsumowanie.pdf (17.04.2016).

Sokołowska E., Innovations in the payment card market: The case of Poland, "Electronic Commerce Research and Applications”, Vol. 14/2015, http://doi.org/10.1016/j. elerap.2015.07.005.

Spath D., Praeg C.P., Korge G., Peeters B., Polasik M., Przenajkowska K., European Trend Survey "BANKS E FUTURE 2012". Trends and Developments in the European Payments Market, Stuttgart 2012. 
Speech by Yves Mersch, Member of the Executive Board of the ECB, at the European Financial Forum dinner, 2015 Cumberland Lodge Financial Services Summit, Cumberland Lodge, 12 November 2015, https://www.ecb.europa.eu/press/key/date/2015/ html/sp151112_1.en.html (17.04.2014).

Stango V., The economics of standards wars, "Review of Network Economics", Vol. 3, No. 1/2004, http://doi.org/10.2202/1446-9022.1040.

Tunay K.B., Tunay N., Akhisar İ., Interaction between Internet banking and bank performance: The case of Europe, "Procedia - Social and Behavioral Sciences", Vol. 195/2015, http://doi.org/10.1016/j.sbspro.2015.06.335.

van der Cruijsen C., Plooij M., Changing payment patterns at point-of-sale: their drivers, “DNB Working Paper", No. 471/2015, http://dx.doi.org/10.2139/ssrn.2602219.

Wannemacher P., L'Hostis A., 2015 Global Mobile Banking Functionality Benchmark, Cambridge 2015.

Ward M., EMV card payments - An update, "Information Security Technical Report", Vol. 11, No. 2/2006, http://doi.org/10.1016/j.istr.2006.03.001.

Węcławski J., Przeksztatcenia polskiego systemu bankowego w latach 1989-2014, "Annales UMCS - Sectio H Oeconomia", Vol. XLIX, No. 1/2015.

Wrzosek W., Strategie marketingowe, PWE, Warszawa 2012. 